\title{
Post Viral Olfactory Dysfunction After SARS-CoV-2 Infection: Anticipated Post-pandemic Clinical Challenge
}

\author{
Dhruv Kapoor $^{1}\left[\right.$ Deha Verma $^{1,2} \cdot$ Neelima Gupta $^{1} \cdot$ Arun Goyal $^{1}$
}

Received: 16 May 2021 / Accepted: 27 June 2021/Published online: 7 July 2021

(C) Association of Otolaryngologists of India 2021

\begin{abstract}
Persistent olfactory dysfunction (OD) is the second most common symptom of post coronavirus disease-19 (COVID-19) now being termed long-COVID. Its prevalence after recovery from COVID-19 is estimated to be $12 \%$ after nearly 6 months of follow-up. It thus becomes imperative for the treating clinicians to update themselves with the pathophysiology of this post COVID disability as well as the tools for diagnosis and the available treatment options. A systematic literature search was performed as per PRISMA guidelines in MEDLINE, Cochrane Library, LILACS, Google Scholar, ClinicalTrials.gov, and medRxiv databases. The keywords used were covid-19, Olfactory Disorders, Smell, Anosmia, PVOD, Post Viral Olfactory Disorders, post-covid and post haul. All articles were studied for definition, mechanism, diagnostic tests and treatment options for post COVID OD. 33 published articles and 8 ongoing trials were found relevant and included after full-text review. SARS-CoV-2 can cause conductive, neural and central OD. Olfactory evaluation can be done both subjectively (visual analogue scale) and objectively (Sniffin' sticks, Sinonasal Outcome Test, University of
\end{abstract}

Neha Verma

dr.neha.verma@gmail.com

Dhruv Kapoor

dkapooralld@gmail.com

Neelima Gupta

drneelimagupta@gmail.com

Arun Goyal

arungoyal150@yahoo.co.in

1 Department of Otorhinolaryngology, University College of Medical Sciences, Delhi, India

2 Present Address: Department of Otorhinolaryngology, Guru Teg Bahadur Hospital, Ward 25, Delhi 110 095, India
Pennsylvania Smell Identification Test and modified Davidson's alcohol sniff test). They can be used to detect and follow-up patients. Despite several on-going clinical trials, the most reliable and advisable treatment option available till date is olfactory training.

Keywords COVID-19 - Olfaction disorders - Anosmia · Post COVID · PVOD · Long-COVID · Post viral

\section{Introduction}

New onset olfactory dysfunction (OD), in the form of hyposmia, anosmia or parosmia, was identified as a conspicuous feature of coronavirus disease 2019 (COVID-19), in the initial months of the pandemic. Albeit ODs in COVID-19 mostly improve within 7-20 days of symptom onset, a significant proportion of survivors (12-65\% after about 1 month of symptom onset) are still left with a lasting debility despite viral clearance [1,2]. With a major portion of world population already infected by SARS$\mathrm{CoV}-2$, there is an expected increase in the proportion of out-patients presenting with such post-viral olfactory disorder (PVOD) in coming months. This population will further be augmented with the advent of COVID-19 vaccine which shows decrease in the severity of disease, to forms which are known to have higher prevalence of OD [3].

The persisting effects of COVID-19 after initial illness are now being termed as long-COVID. In the long run, the treatment of PVOD will be important because it is a common symptom of long-COVID, second only to dyspnea [1]. Despite being regarded as an innocuous symptom, OD leads to a significant impediment in quality of life. This disability is associated with a higher chance of decrease in 
appetite leading to undernutrition, and even depression. Due to the inability to smell for dangerous odours, ODs also pose people at increased risk of injuries which can at times be life-threatening. It thus becomes imperative for treating clinicians to update themselves with the pathophysiology of the PVOD as well as the tools for diagnosis and the available treatment options.

\section{Methods}

A thorough literature search was conducted on the databases MEDLINE, Cochrane Library, LILACS, Google Scholar, ClinicalTrials.gov, and medRxiv between 12-122020 and 21-12-2020 using the MeSH terms covid-19 AND (Olfactory Disorders OR Smell OR Anosmia) and Keywords (covid-19 OR corona virus) AND (PVOD OR Post Viral Olfactory Disorders OR post-covid OR post haul). The search was further augmented by hand-searching of the relevant articles. A total of 1772 articles were found. After a preliminary filtering by titles, 325 articles were selected for abstract review. Finally, 147 articles were taken up for full text review. Of which 42 were eventually found relevant to the subject, which included 8 ongoing clinical trials (registered on ClinicalTrials.gov). Preferred Reporting Items for Systematic Reviews and Meta-Analyses (PRISMA) Flowchart is depicted in Fig. 1. All included articles were studied for definition, mechanism, diagnostic tests and treatment of PVOD after COVID-19.

\section{Discussion}

The prevalence of ODs among patients with active COVID-19, is reported as high as $61 \%$ with an even higher number being detected using objective tests [4]. It is more prevalent in young adults, women and Caucasians and less prevalent in children and elderly [5, 6]. All the more, a staggering $12 \%$ of patients continued to be affected with PVOD after 1.5 to 6 months of remission of COVID-19 [1]. Despite ample research and multiple hypotheses for causation, we have yet to reach a consensus in defining PVOD for starting intervention, and evaluating and treating it.

\section{When to Label PVOD in COVID-19 Patients?}

In their study, Kosugi EM et al. [2] conducted an online survey for sudden onset OD in active COVID-19, and estimated the median time for recovery to be 15 days (IQR 10-21 days) with a full recovery in $52.6 \%$ individuals at the end of 15 days. The recovery was observed to be more frequent in cases of hyposmia in comparison to anosmia. However, $46 \%$ and $19 \%$ individuals reported partial and no
Fig. 1 Preferred reporting items for systematic reviews and meta-analyses (PRISMA) flowchart

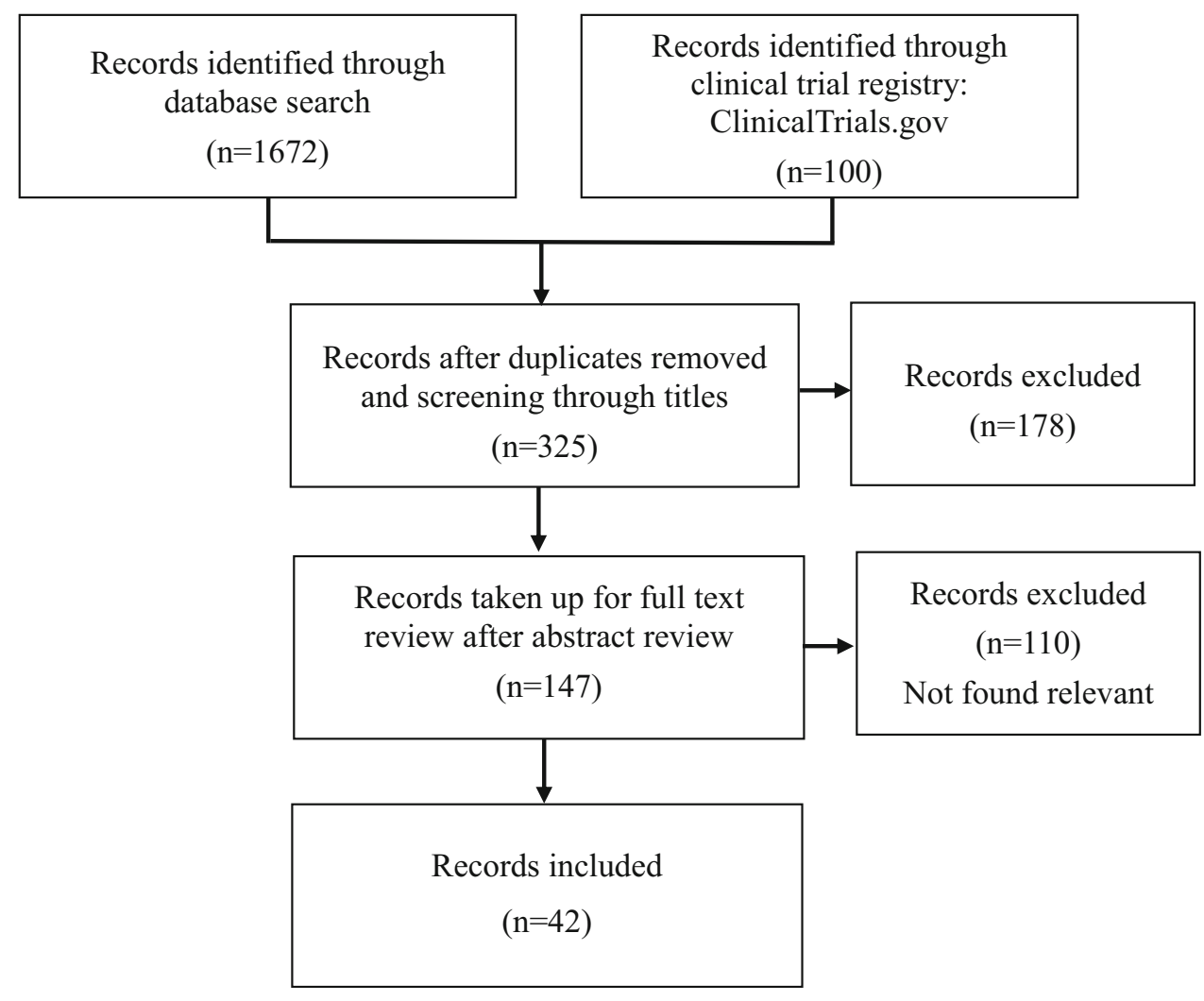


recovery respectively after a median 31 days follow-up. While, Stavem et al. [1] conducted a postal survey for PVOD, and reported $12 \%$ prevalence in COVID-19 survivors, with a median follow-up of 117 days, in a population-based cohort study. Although subjectively, majority of sufferers of sudden onset OD due to COVID-19 infection report improvement in olfaction, objective tests reveal that only half of patients with persistent hyposmia actually realized their persistent disability in olfactory identification and discrimination [7].

In a 60 day prospective objective olfactory assessment of COVID-19 infected patients with sudden onset ODs [8], authors deduced that risk of PVOD became significant after 20 days from onset of OD (odds ratio 58.5, 95\% confidence interval 3.278-1043.5, $\mathrm{p}=0.005)$. The patients with moderate OD at 20 days improved by the end of 60 days observation period, but the $20 \%$ patients in the cohort who had severe OD at end of 20 days, continued to persist with the problem even after 60 days of follow-up period. So, based on the available evidence, patients suffering with persisting OD after 20 days of symptom onset, should be labelled PVOD and considered for therapy. However, a definite consensus is yet to be reached.

\section{How Does SARS-CoV-2 Cause Olfactory Dysfunction?}

Traditionally, ODs due to viral infection are mainly attributed to mucus deposition over the sensory mucosa and decreased air entry, secondary to nasal congestion and rhinorrhoea. But, SARS-CoV-2 is hypothesized to cause OD by all three known ways: conductive dysfunction, by preventing odorant from reaching neuroepithelium; sensorineural dysfunction, by damage/loss of olfactory neuroepithelium or olfactory sensory neurons (OSNs); and central dysfunction, by damage or loss of olfactory processing pathways in the CNS.

Lechien et al. [9] found OC obstruction on computed tomography (CT) scans in 3 of 16 anosmic patients. Eliezer et al. [10] evaluated the olfactory clefts (OCs) and olfactory function in a cohort of OD inflicted COVID-19 patients, and found that early in the disease, patients developed OD as well as OC obstruction, as evident on magnetic resonance imaging (MRI). On follow-up at one month both OD and OC obstruction had improved in most patients except a few, who remained affected with PVOD after 1 month, despite reversal in OC obstruction. However, Kandemirli et al. found olfactory cleft opacification in CT scans of $73.9 \%$ of recovered COVID-19 patients with OD persisting after one month [11]. So, OC obstruction in active COVID-19 may be, in part, responsible for the OD as it prevents inhaled odorants from reaching the olfactory epithelium. Yet, this alone cannot fully explain the persistent and delayed smell disturbances especially in the post recovery and long-haul patients. It is especially interesting to note that, $66.9 \%$ of COVID-19 patients with anosmia do not complain of nasal congestion (cf. other flu illnesses) [5].

The second and the major mechanism of ODs hypothesized in COVID-19 infection is, injury to non-neuronal cells in olfactory epithelium, causing secondary damage to OSNs. These cells include sustentacular cells, microvillar cells, Bowman's gland cells, horizontal basal cells, and olfactory bulb pericytes in olfactory epithelium. Brann et al. found that these cells express angiotensin-converting enzyme-2 (ACE-2) in significantly higher quantities than the surrounding olfactory epithelium. ACE- 2 is the principal mechanism used by the virus for entry into host cell after priming of spike (S) protein using host proteases $[12,13]$. Transmembrane serine protease 2 (TRPMSS2) is one such protease which is also expressed along with ACE2 in similar cells. Higher ACE- 2 expression in adults as compared to the children also correlates with the higher prevalence of the disease in adults [14]. Body reacts to this insult with release of proinflammatory cytokines in the vicinity, especially tumour necrosis factor- $\alpha$ (TNF- $\alpha$ ), first leading to physiological desensitization of OSNs and later neuronal loss, causing sensorineural olfactory loss $[15,16]$. When the insult ceases, OSNs re-sensitize, and in case of neuronal loss, basal cells are able to regenerate new olfactory neurons and the individual eventually regains sense of olfaction.

Since Brann et al. also found that OSNs do not express ACE-2, the aforementioned hypothesis fails to explain the presence of SARS-CoV-2 in brains of murine models which were inoculated with the virus, intranasally [17]. In vitro studies revealed, neuropilin-1 (NRP1) as another host factor which binds to the primed S protein of SARSCoV-2 and is responsible for entry into host cell $[18,19]$. NRP1 is found abundantly in OSNs and axons of mitral cells but not in the olfactory epithelium [20]. In an in silico study by Davies et al., NRP1 was found abundantly expressed in parts of the brain concerned with olfaction, as olfactory tubercles and para-olfactory gyri [21]. It can thus be hypothesized that with the possible role of NRP1, SARS-CoV-2 invades the brain by retrograde axonal transport from nasal cavity, quite similar to human herpes virus [22]. However, more evidence is required for elucidating the exact mechanism. Additional molecules, as BSG and PIKfyve, are also being identified as contributors to mediation of infection [23].

Kandemirli et al. [11] conducted Magnetic Resonance Imaging on COVID-19 recovered patients with OD persisting after one month of onset, and found that, $54.2 \%$ of cases had changes in normal inverted $\mathrm{J}$ shape of the bulb. 91.3\% of cases had abnormality in olfactory bulb signal 
intensity like diffusely increased signal intensity, scattered hyperintense foci or microhaemorrhages. Evident clumping of olfactory filia was seen in $34.8 \%$ of cases and thinning with scarcity of filia in $17.4 \%$. Primary olfactory cortical signal abnormality was seen in $21.7 \%$ of cases. Axiomatically, the resultant axonal injury, neuronal loss and microhaemorrhages in olfactory bulb, can be considered important contributors and an explanation to PVOD in long-COVID.

\section{What Are the Available Tools for Evaluation of Olfactory Dysfunction?}

For long, the Sniffin' Sticks test and Sinonasal Outcome Test (SNOT) - 22 tests were used widely for diagnosing as well as following up of patients with OD. But these tests score low on the scale of feasibility for implementation in the out-patient setting. The COVID-19 pandemic and the need for distancing has led to the invention of new scales and tools for the same purpose which have proved to be both handy as well as helpful in limiting contact with the patients.

Subjective test being used popularly now is visual analogue scale (VAS) of European position paper on rhinosinusitis and nasal polyps (EPOS) which is both feasible and cheap. Among objective tests, a modification of Davidson's alcohol sniff test was tested as a screening tool for COVID19 [24]. It has shown a sensitivity of $75 \%$ in a Phase II trial with odds ratio of 6.56 with $10 \%$ ethanol. It offers a noncumbersome and easy option for screening of COVID-19. Another standardised test available for olfactory identification is University of Pennsylvania Smell Identification Test (UPSIT). It has been proven of value in the pandemic especially because it also limits contact with patient. Although it has been used for evaluating olfaction in Iranians [25] and shown higher detection of OD than subjective tests, it has a certain downside to its use. It is resource intensive as the materials need to be disposed after single use. In addition, a validated set of odorants needs to be prepared for every region pertaining to the differences in culture and food habits of people.

Despite increased availability of tests and questionnaires as screening tools for COVID-19, there is a lack of validated and handy tools for use as point-of-care olfactory tests for diagnosing and following-up OD. There is an ongoing trial at the time of writing this article led by Maes R P in Yale New Haven Hospital for validation of a rapid quantitative test for loss of smell (ClinicalTrials.gov Identifier: NCT04431908).

Otte et al. [26] evaluated the OD objectively in 91 patients after a mean of 57.94 days and concluded that there was a poor correlation between measured olfactory performance and patients' self-assessment as nearly
$51.35 \%$ (19 patients) who had hyposmia objectively, did not realize it. Based on the available evidence, we recommend baseline objective and subjective tests at onset of symptoms in active COVID-19 and only subjective tests in case of PVOD in long-COVID, to target the subjective relief in symptoms.

\section{What Are the Options for Treatment of PVOD?}

Throughout the past year of pandemic, the modality of treatment for persistent OD has been debated. Physicians have used olfactory training, saline nasal irrigations and corticosteroids, both intranasal and systemic, for initiation of treatment for OD $[2,27]$. Treatment options for persistent OD after viral infections, in general, has been systematically reviewed by Hura $\mathrm{N}$ et al. based on the evidence of the studies of which they have recommended olfactory training to be the best treatment modality [28]. Specifically for PVOD after COVID-19, there is a repertoire of pharmacological options, but are yet to be proven. Table 1 enlists the ongoing trials for for potential pharmacological options for treatment of PVOD in longCOVID at the time of writing the article. For prevention of PVOD, in vitro studies have shown that a protease inhibitor, camostat mesylate, inhibits the cell entry of SARS$\mathrm{CoV}-2$ and thus is a potential therapeutic agent during active COVID-19 [29]. It has also been hypothesized that nasal lavage with ACE-2 antagonist or angiotensin receptor blocker will also help in reducing viral load in COVID-19, which we believe, can in turn can decrease the incidence and severity of PVOD itself [30].

Olfactory Training (OT) is a promising and cost-effective solution to sensorineural olfactory loss [31]. It is based on the principle similar to that of physical therapy after a neurologic insult or balance therapy for vestibular disease. After a neural insult, repeated stimulation and retraining can help reorganize functional network with a resultant significant gain of function or compensation [32]. Traditional OT involves exposure to four intense odours twice daily [33]. Modified OT involves exposure to 3 sets of 4 different odours, changed every 12 weeks [34]. This exercise is generally done for at least 6 to 8 months. Both traditional and modified OT are shown to have a significant improvement in olfaction, although the superiority of either one has not been clearly established. A higher efficacy of high concentration odorants has also been demonstrated over low concentration odorants in OT for post infectious OD [35]. A harmless intervention as OT can be considered early in the disease. However, it is practically irrelevant to implement en masse an intervention with high demand of manpower, considering majority of olfactory dysfunctions in COVID-19 are reversible. A better OT programme can 
Table 1 List of clinical trials on post viral olfactory dysfunction after coronavirus disease-19 registered with ClinicalTrials.gov

\begin{tabular}{|c|c|c|c|c|c|c|}
\hline $\begin{array}{l}\text { Principal } \\
\text { investigator } \\
\text { (ClinicalTrials.gov } \\
\text { Identifier) }\end{array}$ & Drug/intervention & Phase & Study type & $\begin{array}{l}\text { Primary } \\
\text { outcome(s) }\end{array}$ & $\begin{array}{l}\text { Secondary } \\
\text { outcome(s) }\end{array}$ & Rationale \\
\hline $\begin{array}{l}\text { Iloreta AM } \\
\text { (NCT04495816) }\end{array}$ & $\begin{array}{l}\text { Omega-3 Fatty Acid } \\
\text { Supplement versus Placebo }\end{array}$ & 2 & $\begin{array}{l}\text { Randomised, } \\
\text { parallel arm } \\
\text { Control Trial }\end{array}$ & $\begin{array}{l}\text { BSIT at } \\
\text { Week } 0 \\
\text { Week } 6\end{array}$ & $\begin{array}{l}\text { 1. mQOD-NS } \\
\text { at } \\
1 \text { week } \\
2 \text { weeks } \\
4 \text { weeks } \\
6 \text { weeks } \\
2 . \text { SNOT-22 } \\
\text { at } \\
1 \text { week } \\
2 \text { weeks } \\
4 \text { weeks } \\
6 \text { weeks }\end{array}$ & $\begin{array}{l}\text { Preclinincal studies have } \\
\text { shown improvement in OD } \\
\text { in mice receiving the drug } \\
\text { RCT in humans receiving the } \\
\text { drug after endoscopic } \\
\text { endonasal skull base } \\
\text { surgery have shown greater } \\
\text { return of normal olfaction }\end{array}$ \\
\hline $\begin{array}{l}\text { Abdelalim AA } \\
\text { (NCT04484493) }\end{array}$ & $\begin{array}{l}\text { Mometasone furoate nasal spray } \\
\text { dose of } 2 \text { puff in each nostril } \\
(100 \mu \mathrm{g} \text { once daily each } \\
\text { nostril) alongwith Olfactory } \\
\text { Trining versus only Olfactory } \\
\text { Training }\end{array}$ & 3 & $\begin{array}{l}\text { Randomised, } \\
\text { parallel arm, } \\
\text { clinical trial }\end{array}$ & $\begin{array}{l}\text { Improvement } \\
\text { of olfaction } \\
\text { after } 3 \text { weeks } \\
\text { in subjective } \\
\text { scoring of } \\
0-10\end{array}$ & NP & $\begin{array}{l}\text { Olfactory improvement } \\
\text { improved with the drug in } \\
\text { other PVOD [28] }\end{array}$ \\
\hline $\begin{array}{l}\text { NP (Trial not yet } \\
\text { recruiting at the } \\
\text { time of writing } \\
\text { this article) } \\
\text { (NCT04422275) }\end{array}$ & $\begin{array}{l}\text { Four study arms: Budesonide } \\
\text { nasal lavage with OT with } \\
\text { high concentration essential } \\
\text { oils; Placebo with OT with } \\
\text { high concentration essential } \\
\text { oils; Budesonide nasal lavage } \\
\text { with OT with low } \\
\text { concentration essential oils; } \\
\text { placebo with OT with low } \\
\text { concentration essential oils }\end{array}$ & 2 & $\begin{array}{l}\text { Blinded } \\
\text { Randomised, } \\
\text { parallel arm } \\
\text { clinical trial }\end{array}$ & $\begin{array}{l}\text { UPSIT at Week } \\
0,12 \text { and } 24\end{array}$ & $\begin{array}{l}\text { 1. QOD-NS } \\
\text { between } \\
\text { baseline and } \\
\text { assessment } \\
\text { time frame } \\
\text { 2. Global } \\
\text { Rating of } \\
\text { Smell at } \\
12 \text { weeks } \\
\text { 3. Global } \\
\text { Rating of } \\
\text { Change of } \\
\text { Smell at } \\
12 \text { weeks } \\
\text { and } \\
24 \text { weeks }\end{array}$ & $\begin{array}{l}\text { Olfactory improvement } \\
\text { improved with the drug } \\
\text { and OT in other PVOD }\end{array}$ \\
\hline $\begin{array}{l}\text { Al-Ani RM } \\
\text { (NCT04569825) }\end{array}$ & $\begin{array}{l}\text { Steroid (Ophtamesone) local } \\
\text { application intranasally as } \\
\text { drops versus normal saline } \\
\text { drops }\end{array}$ & 1 & $\begin{array}{l}\text { Randomised } \\
\text { parallel-arm } \\
\text { clinical trial }\end{array}$ & $\begin{array}{l}\text { Recovery rate } \\
\text { of anosmia } \\
\text { and recovery } \\
\text { time }\end{array}$ & NP & $\begin{array}{l}\text { Olfactory improvement } \\
\text { improved with the drug in } \\
\text { other PVOD }\end{array}$ \\
\hline $\begin{array}{l}\text { Issak ER } \\
\text { (NCT04528329) }\end{array}$ & $\begin{array}{l}\text { Early Dexamethsone: early use } \\
\text { of dexamethasone as early as } \\
\text { laboratory evidence of high } \\
\text { inflammatory markers versus } \\
\text { Late Dexamethsone: Use of } \\
\text { dexamethasone on } \\
\text { deterioration of the cases with } \\
\text { increased severity }\end{array}$ & 4 & $\begin{array}{l}\text { Open-label } \\
\text { randomised, } \\
\text { parallel arm, } \\
\text { clinical trial }\end{array}$ & $\begin{array}{l}\text { Time to } \\
\text { recovery } \\
\text { (1-6 weeks) }\end{array}$ & NP & NP \\
\hline
\end{tabular}


Table 1 continued

\begin{tabular}{|c|c|c|c|c|c|c|}
\hline $\begin{array}{l}\text { Principal } \\
\text { investigator } \\
\text { (ClinicalTrials.gov } \\
\text { Identifier) }\end{array}$ & Drug/intervention & Phase & Study type & Primary outcome(s) & $\begin{array}{l}\text { Secondary } \\
\text { outcome(s) }\end{array}$ & Rationale \\
\hline $\begin{array}{l}\text { Daval M et al. } \\
\text { (NCT04361474) }\end{array}$ & $\begin{array}{l}\text { Budesonide saline nasal } \\
\text { irrigation with olfactory } \\
\text { rehabilitation twice a day } \\
\text { vs saline nasal irrigation } \\
\text { with olfactory } \\
\text { rehabilitation twice a day }\end{array}$ & 3 & $\begin{array}{l}\text { Randomised } \\
\text { Parallel } \\
\text { Arm } \\
\text { Clinical } \\
\text { Trial }\end{array}$ & $\begin{array}{l}\text { Percentage of patients } \\
\text { with an improvement } \\
\text { of more than } 2 \text { points } \\
\text { on the ODORATEST } \\
\text { score (5) after } 30 \text { days } \\
\text { of treatment }\end{array}$ & NP & $\begin{array}{l}\text { The treatment of viral } \\
\text { hyposmias is based on } \\
\text { local and/or general } \\
\text { corticosteroid treatment } \\
\text { combined with saline nasal } \\
\text { irrigation at the onset of } \\
\text { signs. To avoid } \\
\text { development of severe } \\
\text { forms of COVID-19, local } \\
\text { treatment with } \\
\text { corticosteroids could be } \\
\text { instituted from } 30 \text { days } \\
\text { after the onset of } \\
\text { symptoms of COVID-19 } \\
\text { without risk of } \\
\text { dissemination }\end{array}$ \\
\hline $\begin{array}{l}\text { Mohamed S } \\
\quad(\text { NCT04657809) }\end{array}$ & $\begin{array}{l}\text { Formulated bioadhesive fast } \\
\text { dissolving film containing } \\
\text { 100IU insulin versus } \\
\text { placebo fast } \\
\text { dissolving film with no } \\
\text { drug }\end{array}$ & 2 & $\begin{array}{l}\text { Randomised } \\
\text { Parallel } \\
\text { Arm } \\
\text { Clinical } \\
\text { Trial }\end{array}$ & $\begin{array}{l}\text { Smell sensation } \\
\text { improvement by } \\
\text { decrease in the } \\
\text { threshold sensation } \\
\text { with butanol test at end } \\
\text { of } 4 \text { weeks }\end{array}$ & NP & NP \\
\hline
\end{tabular}

$B S I T$ brief smell identification test, $m Q O D-N S$ modified brief questionnaire of olfactory dysfunction, $N P$ not provided, $O T$ olfactory training, SNOT-22 sinonasal outcome test

be planned once a consensus is reached for definition of PVOD.

\section{What Are the Potential Areas of Future Research?}

An improved understanding is required for the exact mechanism of neuronal injury leading to long-term and permanent disability. An anticipated increase in patients with OD also warrants for better and feasible tests for its evaluation which have a higher diagnostic accuracy, ease of performance and suitability for repeated use during follow-up in the out-patient setting. There is an urgent need to define the timeline for PVOD whence treatment should be initiated. There is a dearth of information for recommending a pharmacological option as of now. So, olfactory training remains the cornerstone in management of such patients. Despite the ongoing trials comparing various treatment options for post-COVID OD, there is a continued need to study the role of inflammatory mediators and use of their inhibitors in reducing and reverting this disability. There is a need of randomized trials for proving efficacy of OT over other modalities especially in case of post viral olfactory dysfunction.

\section{Conclusion}

Post-viral Olfactory Dysfunction is an important clinical entity, and with the resumption of health services, the attendance of post-COVID patients demanding its solution is highly likely to increase in the coming months. Olfactory dysfunction warrants attention and intervention, if it persists after 20 days of symptom onset. SARS-CoV-2 is hypothesized to cause olfactory dysfunction by all three possible means: conductive, sensorineural and central. Even though, objective assessment of olfactory dysfunction is more reliable, especially for detection of persistent hyposmia, subjective tests should be preferred in cases with persistent dysfunction as the target is alleviation of symptoms. Olfactory training is the mainstay of treatment and rehabilitation at present.

\section{Funding None.}

\section{Declarations}

Conflict of interest None of the authors have any competing interests. 


\section{References}

1. Stavem K, Ghanima W, Olsen MK, Gilboe HM, Einvik G (2020) Persistent symptoms 1.5-6 months after COVID-19 in non-hospitalised subjects: a population-based cohort study. Thorax [Internet]. 2020 Dec 3 [cited 2020 Dec 19]; thoraxjnl-2020-216377. https://www.thorax.bmj.com/lookup/doi/ https://doi.org/10.1136/thoraxjnl-2020-216377

2. Kosugi EM, Lavinsky J, Romano FR, Fornazieri MA, Luz-Matsumoto GR, Lessa MM et al (2020) Incomplete and late recovery of sudden olfactory dysfunction in COVID-19. Braz J Otorhinolaryngol [Internet]. 2020 [cited 2020 Dec 19]; 86(4):490-496. https://pubmed.ncbi.nlm.nih.gov/32534982/

3. Pfizer, Oxford COVID-19 vaccines reduces severity of the disease in elderly: pre-print study - Health News, Firstpost [Internet]. [cited 2021 Mar 3]. https://www.firstpost.com/he alth/pfizer-oxford-covid-19-vaccines-reduces-severity-of-thedisease-in-elderly-pre-print-study-9369331.html

4. Hajikhani B, Calcagno T, Nasiri MJ, Jamshidi P, Dadashi M, Goudarzi $\mathrm{M}$ et al (2020) Olfactory and gustatory dysfunction in COVID-19 patients: a meta-analysis study. Physiol Rep [Internet]. 2020 Sep [cited 2020 Dec 15]; 8(18):e14814. https://pubmed.ncbi.nlm.nih.gov/32975884/

5. Von Bartheld CS, Butowt R, Hagen MM (2020) Prevalence of chemosensory dysfunction in COVID-19 patients: a systematic review and meta-analysis reveals significant ethnic differences. ACS Chem Neurosci [Internet]. 2020 Oct 7 [cited 2020 Dec 15]; 11(19):2944-2961. https://pubmed.ncbi.nlm.nih.gov/32870641/

6. Somekh I, Yakub Hanna H, Heller E, Bibi H, Somekh E (2020) Age-dependent sensory impairment in COVID-19 infection and its correlation with ACE2 expression. Pediatr Infect Dis J [Internet]. 2020 Sep [cited 2020 Dec 17]; 39(9):e270-e272. https://pubmed.ncbi.nlm.nih.gov/32658093/

7. Otte MS, Klussmann JP, Luers JC (2020) Persisting olfactory dysfunction in patients after recovering from COVID-19. J Infect [Internet]. 2020 Sep [cited 2020 Dec 22]; 81(3):e58. https:// pesquisa.bvsalud.org/portal/resource/en/mdl-32592702

8. Vaira LA, Hopkins C, Petrocelli M, Lechien JR, Chiesa-Estomba CM, Salzano G et al (2020) Smell and taste recovery in coronavirus disease 2019 patients: a 60-day objective and prospective study. J Laryngol Otol [Internet]. 2020 Aug [cited 2020 Dec 19]; 134(8):703-709.

https://www.cambridge.org/core/product/identifier/ S0022215120001826/type/journal_article

9. Lechien JR, Michel J, Radulesco T, Chiesa-Estomba CM, Vaira LA, De Riu G et al (2020) Clinical and radiological evaluations of COVID-19 patients with anosmia: preliminary report. Laryngoscope [Internet]. 2020 Nov [cited 2021 Jan 2]; 130(11):2526-2531. https://pubmed.ncbi.nlm.nih.gov/32678494/

10. Eliezer M, Hamel A-L, Houdart E, Herman P, Housset J, Jourdaine $\mathrm{C}$ et al (2020) Loss of smell in COVID-19 patients: MRI data reveals a transient edema of the olfactory clefts. Neurology [Internet]. 2020 Dec 8 [cited 2020 Dec 17]; 95(23):e3145-e3152. https://pubmed.ncbi.nlm.nih.gov/32917809/

11. Kandemirli SG, Altundag A, Yildirim D, Tekcan Sanli DE, Saatci O (2021) Olfactory bulb MRI and paranasal sinus CT findings in persistent COVID-19 anosmia. Acad Radiol [Internet]. 2021 Jan [cited 2020 Dec 15]; 28(1):28-35. https://pubmed.ncbi.nlm.nih. gov/33132007/

12. Brann DH, Tsukahara T, Weinreb C, Lipovsek M, Van Den Berge K, Gong B et al (2020) Non-neuronal expression of SARSCoV-2 entry genes in the olfactory system suggests mechanisms underlying COVID-19-associated anosmia. Sci Adv [Internet]. 2020 Jul 31 [cited 2020 Dec 22]; 6(31). https://pesquisa.bvsalud.org/portal/resource/en/mdl-32937591
13. Bilinska K, Jakubowska P, Von Bartheld CS, Butowt R (2020) Expression of the SARS-CoV-2 entry proteins, ACE2 and TMPRSS2, in cells of the olfactory epithelium: identification of cell types and trends with age. ACS Chem Neurosci [Internet]. 2020 Jun 3 [cited 2020 Dec 22]; 11(11):1555-1562. https://www.ncbi.nlm.nih.gov/pmc/articles/PMC7241737/

14. Chen M, Shen W, Rowan NR, Kulaga H, Hillel A, Ramanathan $M$ et al (2020) Elevated ACE-2 expression in the olfactory neuroepithelium: implications for anosmia and upper respiratory SARS-CoV-2 entry and replication. Eur Respir J [Internet]. 2020 Sep 24 [cited 2020 Dec 15]; 56(3):2001948. https://pubmed. ncbi.nlm.nih.gov/32817004/

15. Torabi A, Mohammadbagheri E, Akbari Dilmaghani N, Bayat AH, Fathi M, Vakili K et al (2020) Proinflammatory cytokines in the olfactory mucosa result in COVID-19 induced anosmia. ACS Chem Neurosci [Internet]. 2020 Jul 1 [cited 2020 Dec 22]; 11(13):1909-1913. https://pesquisa.bvsalud.org/portal/resource/en/mdl-32525657

16. Lane AP, Turner J, May L, Reed R (2010) A genetic model of chronic rhinosinusitis-associated olfactory inflammation reveals reversible functional impairment and dramatic neuroepithelial reorganization. J Neurosci [Internet]. 2010 Feb 10 [cited 2020 Dec 25]; 30(6):2324-2329. https://www.jneurosci.org/ content $/ 30 / 6 / 2324$

17. Netland J, Meyerholz DK, Moore S, Cassell M, Perlman S (2008) Severe acute respiratory syndrome coronavirus infection causes neuronal death in the absence of encephalitis in mice transgenic for human ACE2. J Virol [Internet]. 2008 Aug [cited 2020 Dec 27]; $\quad$ 82(15):7264-7275. https://pubmed.ncbi.nlm.nih.gov/ $18495771 /$

18. Daly JL, Simonetti B, Klein K, Chen KE, Williamson MK, Antón-Plágaro C et al (2020) Neuropilin-1 is a host factor for SARS-CoV-2 infection. Science [Internet]. 2020 Nov 13 [cited 2021 Jan 2]; 370(6518):861-865. https://pubmed.ncbi.nlm.nih. gov/33082294/

19. Cantuti-Castelvetri L, Ojha R, Pedro LD, Djannatian M, Franz J, Kuivanen $S$ et al (2020) Neuropilin-1 facilitates SARS-CoV-2 cell entry and infectivity. Science (80- ) [Internet]. 2020 Nov 13 [cited 2021 Jan 2]; 370(6518):856-860. https://pubmed.ncbi. nlm.nih.gov/33082293/

20. Kawakami A, Kitsukawa T, Takagi S, Fujisawa H (1996) Developmentally regulated expression of a cell surface protein, neuropilin, in the mouse nervous system. J Neurobiol [Internet]. 1996 Jan [cited 2021 Jan 3]; 29(1):1-17. https://pubmed.ncbi. nlm.nih.gov/8748368/

21. Davies J, Randeva HS, Chatha K, Hall M, Spandidos DA, Karteris E et al (2020) Neuropilin-1 as a new potential SARS-CoV-2 infection mediator implicated in the neurologic features and central nervous system involvement of COVID-19. Mol Med Rep [Internet]. 2020 Nov [cited 2021 Jan 2];2 2(5):4221-4226. https://pubmed.ncbi.nlm.nih.gov/33000221/

22. Han AY, Mukdad L, Long JL, Lopez IA (2020) Anosmia in COVID-19: mechanisms and significance [Internet]. Vol. 45, Chemical Senses. Oxford University Press; 2020 [cited 2020 Dec 19]. p. 423-8. https://academic.oup.com/chemse/article/45/6/ $423 / 5859163$

23. Chee J, Wang DY (2021) Understanding COVID-19-related olfactory dysfunction. JAMA Otolaryngol-Head Neck Surg [Internet]. 2020 Nov 19 [cited 2021 Feb 7]; 146(7):672-674. http://www.biorxiv.org/content/ https://doi.org/10.1101/2020.03.25.009084v4

24. Calvo-Henriquez C, Maldonado-Alvarado B, Chiesa-Estomba C, Rivero-Fernández I, Sanz-Rodriguez M, Villarreal IM et al (2020) Ethyl alcohol threshold test: a fast, reliable and affordable olfactory Assessment tool for COVID-19 patients. Eur Arch Oto- 
Rhino-Laryngology [Internet]. 2020 Oct [cited 2020 Dec 19]; 277(10):2783-2792. https://pubmed.ncbi.nlm.nih.gov/32583183/

25. Moein ST, Hashemian SMR, Mansourafshar B, Khorram-Tousi A, Tabarsi P, Doty RL (2020) Smell dysfunction: a biomarker for COVID-19. Int Forum Allergy Rhinol [Internet]. 2020 Aug [cited 2020 Dec 18]; 10(8):944-950. https://pubmed.ncbi.nlm.nih.gov/ 32301284/

26. Otte MS, Eckel HNC, Poluschkin L, Klussmann JP, Luers JC (2020) Olfactory dysfunction in patients after recovering from COVID-19. Acta Otolaryngol [Internet]. 2020 Dec [cited 2020 Dec 17]; 140(12):1032-1035. https://pubmed.ncbi.nlm.nih. gov/32852240/

27. da Costa KVT, Carnaúba ATL, Rocha KW, de Andrade KCL, Ferreira SMS, Menezes PdeL (2020) Olfactory and taste disorders in COVID-19: a systematic review [Internet]. Vol. 86, Brazilian Journal of Otorhinolaryngology. Elsevier Editora Ltda; 2020 [cited 2020 Dec 22]. pp 781-92. https://pubmed.ncbi. nlm.nih.gov/32580925/

28. Hura N, Xie DX, Choby GW, Schlosser RJ, Orlov CP, Seal SM et al (2020) Treatment of post-viral olfactory dysfunction: an evidence-based review with recommendations [Internet]. Vol. 10, International Forum of Allergy and Rhinology. John Wiley and Sons Inc; 2020. pp 1065-86. https://onlinelibrary.wiley.com/doi/ full/https://doi.org/10.1002/alr.22624

29. Hoffmann M, Kleine-Weber H, Schroeder S, Krüger N, Herrler $\mathrm{T}$, Erichsen $\mathrm{S}$ et al (2020) SARS-CoV-2 cell entry depends on ACE2 and TMPRSS2 and is blocked by a clinically proven protease inhibitor. Cell [Internet]. 2020 Apr 16 [cited 2021 Jan 2]; 181(2):271-280.e8. https://pubmed.ncbi.nlm.nih.gov/3214 2651/

30. Vofo G, Brodie R, Gross M (2020) Nasal lavage containing Angiotensin-Converting Enzyme-2 agonist can prevent and reduce viral load in COVID-19. Med Hypotheses [Internet]. 2020
Nov [cited 2020 Dec 17]; 144:110207. https://pubmed. ncbi.nlm.nih.gov/33254514/

31. Soler ZM, Patel ZM, Turner JH, Holbrook EH (2020) A primer on viral-associated olfactory loss in the era of COVID-19. Int Forum Allergy Rhinol [Internet]. 2020 Jul [cited 2021 Jan 3]; 10(7):814-820. https://onlinelibrary.wiley.com/doi/abs/https:// doi.org/10.1002/alr.22578

32. Kollndorfer K, Fischmeister FPS, Kowalczyk K, Hoche E, Mueller CA, Trattnig S et al (2015) Olfactory training induces changes in regional functional connectivity in patients with longterm smell loss. NeuroImage Clin [Internet]. 2015 Sep 15 [cited 2021 Jan 3]; 9:401-410. https://pubmed.ncbi.nlm.nih.gov/ 26594622/

33. Hummel T, Reden KRJ, Hähner A, Weidenbecher M, Hüttenbrink KB (2009) Effects of olfactory training in patients with olfactory loss. Laryngoscope [Internet]. 2009 Mar [cited 2021 Jan 29]; 119(3):496-499. https://pubmed.ncbi.nlm.nih.gov/ 19235739/

34. Altundag A, Cayonu M, Kayabasoglu G, Salihoglu M, Tekeli H, Saglam O et al (2015) Modified olfactory training in patients with postinfectious olfactory loss. Laryngoscope [Internet]. 2015 Aug [cited 2021 Jan 29]; 125(8):1763-1766. https://pubmed.ncbi.nlm. nih.gov/26031472/

35. Damm M, Pikart LK, Reimann H, Burkert S, Göktas Ö, Haxel B et al (2014) Olfactory training is helpful in postinfectious olfactory loss: a randomized, controlled, multicenter study. Laryngoscope [Internet]. 2014 Apr [cited 2021 Mar 3]; 124(4):826-31. https://pubmed.ncbi.nlm.nih.gov/23929687/

Publisher's Note Springer Nature remains neutral with regard to jurisdictional claims in published maps and institutional affiliations. 